\title{
Potential Challenges of Cassava Cultivation in South Africa
}

\author{
Elie Fereche Itoba-Tombo* ${ }^{1}$, Seteno Karabo Obed Ntwampe ${ }^{1}$, Felix Nchu ${ }^{2}$ and John Baptist Mudumbi ${ }^{1}$
}

\begin{abstract}
Worldwide, cassava (Manhiot esculenta Crantz) is used for a multitude of reasons; as a main food staple in Africa (Nigeria, Ghana, Cameroun etc.), Asia (Indonesia, Thailand, Cambodia etc.) and South America (Bazil, Paraguay etc.) as well as a source of energy for biogas and biofuel in Asia (China, Indonesia etc), South America (Brazil, Columbia etc.). A high demand of energy due to rapid urbanisation and development in developing countries, prompted governments, scientists and NGOs to seek other environmentally benign methods of energy production than fossil fuel based energy production systems. Thus, cassava has been identified as one of the suitable crops for biogas and biofuel production in order to mitigate the ensuing high energy demand. Like many developing countries, South Africa is interested in achieving sustainable energy and food supply, and cassava can serve as a source of both bioenergy bioethanol and biogas as well as food. However, the establishment/perennial production of cassava in developing countries generally and in South Africa particularly is facing potential challenges such as infertile land, pests problems, climate change and land availability for cultivation. However, some of this challenges can be overcome through availability of land for cassava cultivation, pest (insects) control, creation of local markets leading to job opportunities and communities acceptance of the crop for self-nourishment and industrial use.
\end{abstract}

Keywords - Cassava (Manhiot esculenta), Cultivation, Climate, Pest control, Potential challenges, land availability.

\section{INTRODUCTION}

High demand of energy production and consumption in South Africa (SA) prompted the need of alternative sources of energy production. Thus, cassava (Manhiot esculenta Crantz) has been identified as a one potential source of raw material for bioenergy production (i.e biofuel, and bioethanol) due to its

E. F. Itoba-Tombo Author is with the Department of Environmental and Occupational Studies, Bioresource Engineering Research Group (BioERG) Faculty of Applied Sciences, Cape Peninsula University of Technology, P.O. Box 652, Cape Town 8000South Africa

S.K.O. Ntwampe Author is with Bioresource Engineering Research Group (BioERG), Department of Biotechnology, Cape Peninsula University of Technology, P.O. Box 652, Cape Town 8000, South Africa ;

F. Nchu, Author is with the Department of Horticulture, Cape Peninsula University of Technology, P.O. Box 652, Cape Town 8000, South Africa.

John Baptist Mudumbi Author is with Bioresource Engineering Research Group (BioERG), Department of Biotechnology, Cape Peninsula University of Technology, P.O. Box 652, Cape Town 8000, South Africa high content of biomass [1]. It has an estimated carbohydrate content of $4.742 \mathrm{~kg} / \mathrm{carb} / \mathrm{per}$ hectare, a starch content of $20-35 \%$ (fresh) with $80.6 \%$ (dry weight) and total dry matter $(38.6 \%)$ [2]. Whereas, waste (peels and pulp) generated during cassava products processing is used for bioethanol and biogas production [3]-[5].

Despite the fact that cassava crop is highly cultivated in Africa, Asia and South America as it is a main staple food for the communities due to its nutritional and dietary values [6], [7]; there is an increasing and industrial production of the cultivar mostly for bioenergy production due to an ever increasing energy demand in developing countries [7]-[11]. Thus, a study by [7] revealed an increase in a global cassava production trend of $13 \%$ to $55 \%$ amid 2002-2013. Worldwide in general and in countries situated within the tropics in particular, cassava cultivation is hampered by an invasion of a variety of pests i.e. whiteflies, mealybugs, lacebugs, mites, hornworms etc. [12]. However, the cassava production of such a crop in SA for bioenergy production could be hindered by several challenges including pests, land unavailability, land infertility, drought, climate change etc. Thus, this paper seeks to highlight; the potential challenges facing cassava production within the country, and presented a case study of cassava mealy bug infestation of cassava plant in Cape Town. We also present the possible mitigation interventions that would enable a successful cultivation of cassava in South Africa.

\section{CHALLENGES OF CASSAVA CULTIVATION}

A successful cassava cultivation in South Africa could experience several challenges ranging from insects/pests control, land availability, climate change, lack of markets etc.

\section{A. Climate change}

Climate change has been an important determining factor for agricultural production in general and cassava plant cultivation in particular. Previous studies revealed that pests attacks such as those from; hornworms, mites, whiteflies, mealybugs, lacebugs, etc. are prone to tropical areas [7], [12]-[15].

Climate change with its consequence of changing in weather patterns such as; high temperature, drought and heavy rain are responsible for the proliferation of pests in many regions around the world. Thus, South Africa is not exempt from climate change effects. In recent years the country (SA) has been experiencing drastic changes in its weather patterns due to climate change and global warming [7], [15].

Therefore, changes noticed in weather conditions (i.e. high temperature, drought etc.) recently observed in areas of the country (SA) such as Cape Town known for cold weather, to 
experience high temperatures (i.e. temperatures of $35^{\circ} \mathrm{C}$ ) which is favorable cassava growth, could lead to pests propagation as well as hinder the cultivation of such crop for industrial purpose such as energy production.

\section{B. Land availability}

As a semi-arid country, south Africa sections of land are covered by desert while, others are constitute of mountains that are mostly rocky mountains thus, hostile for agricultural activity in general and cassava production in particular. According to [16], only $12 \%$ of the country's land is suitable for crops production. Thus, from the $12 \%$, only $3 \%$ is considered fertile land. Furthermore, nearly (69\%) of the country's (South Africa) land is appropriate and available for livestock farming and grazing [16].

\section{Lack of markets}

Cassava (Manhiot esculenta Crantz) is highly cultivated in many countries in Africa, Asia and Latin America for self-nourishment and energy production. However, the cultivar is unknown to the majority of South African community-thus, leading to the lack of markets. For example, during our visit to Mbizana for cassava's stems collection, the only lady (Mam Mhlongo) who is cultivating the cultivar, stressed about the lack of awareness on cassava nutritional values from the South African community in general. Therefore, we understood that a lack of awareness from the community constitutes an obstacle for the introduction of the cultivar within those community thus, leads to the lack of markets to sell the cultivated product.

CASE STUDY: First report of mealybug infestations of cassava in Cape Town.

Cassava stems were collected from Bizana in the Eastern Cape province of South Africa for a research on a possible cassava cultivation in Cape Town in particular. After few weeks of plants growth in a Glass/Greenhouse, there were pests (mealybug, red spider mites) infestations of the young plants.

\section{MATERIAL AND METHODS}

\section{A. Cassava growth}

cassava (Manhiot esculenta Crantz) stems were obtained in Mbizana, a town situated in the province of Eastern Cape (South Africa) with geographical coordinates $\left(31.5667^{\circ} \mathrm{S}\right.$, $29.4000^{\circ} \mathrm{E}$ ). The stems of $7-10 \mathrm{~cm}$ long laid into plastic trays containing nursery matrices (mix soil). The plastic trays were placed in a glass/greenhouse at the Cape Peninsula University of Technology (CPUT). A glass/greenhouse had a regulated temperature from a heating fan ranging between $18-19^{\circ} \mathrm{C}$ at night and $23-25^{\circ} \mathrm{C}$ during the day while, a watering system irrigated the trays with cuttings three times a day for a duration of 3 to 4 weeks prior being moved to another section for more solar radiation. At the latest location young plants were irrigated twice daily at a rate of 2-3 minutes/sequence while the humidity was set at $40-60 \%$.
After fourteen weeks the plants were placed into $4 \mathrm{~kg}$ plastic bags containing nursery matrices and moved to an empty glass/greenhouse while being irrigated twice a week coupled by a 3:2:1 NPK (nitrogen:phosphorous:potassium) fertilizer addition into soil. Finally, after 20 weeks of growth plants were then moved into10kg bags.

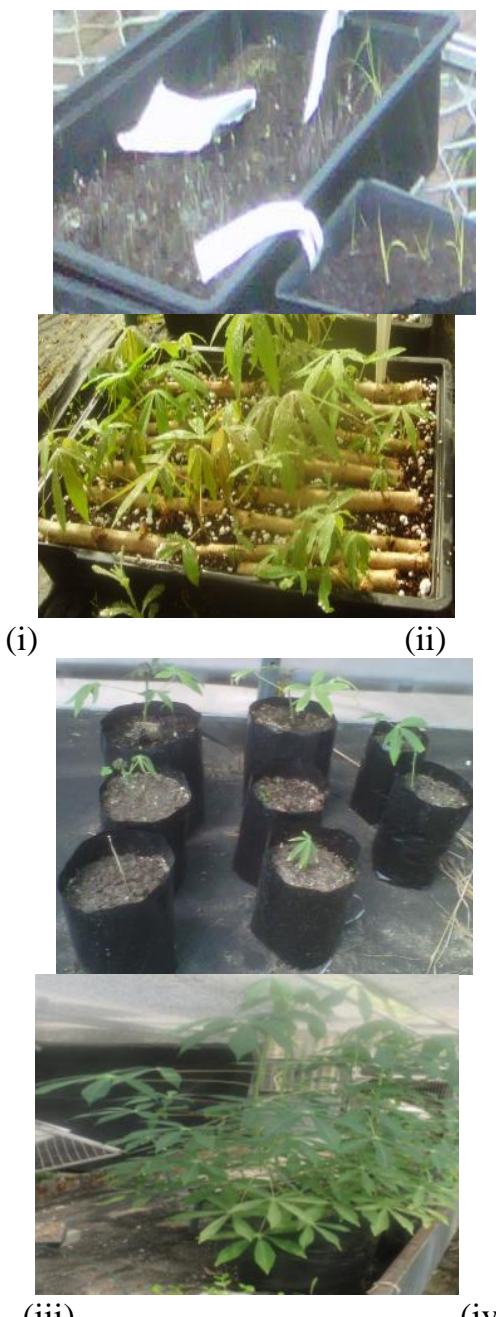

(iii) (iv)

Fig. 1: plants growth Stages (i): cuttings in the plastic trays, (ii)plants shoot of 2-3 weeks, (iii)- young plants in $4 \mathrm{~kg}$ bags, (iv)plants in $10 \mathrm{~kg}$ bags

\section{B. Insects/pests invasion}

Cassava crops cultivated in the CPUT glass/green houses were invaded by pests such as; Mealybug (Phenacoccus manihoti) and red spider mites (Tetranychus urticae) (Figure 2). Pests invasion was noticed from 4 weeks of plants growth onward. Mealybugs presence was characterized by the presence of woolly white/creamy (with pink stains) drops like or eggs around on the apex (extreme soft) part of the plants. Few days later, individual mealybugs were separated from a woolly pack of eggs (Figure 2 (i)). While, the insects attack on plants was characterized by a distortion of a stem a shrinking of plants leaves (Figure 2). 


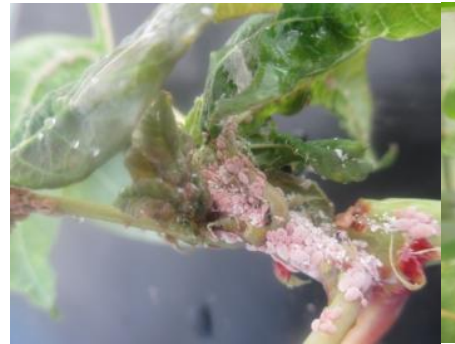

(i)

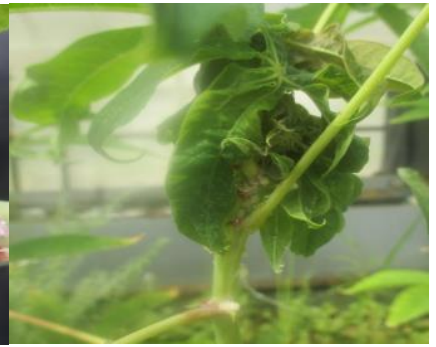

(ii)
Fig. 2: Mealybug (Phenacoccus manihoti) eggs, babies and adults on young cassava plant (i), adults mealybug the upper part of a cassava plant (ii).

Additionally, red spider mites (Tetranychus urticae) attacks on plants were also observed. Thus, the insects attacks were manifest on plants from 3- 17 weeks even above. The attacks were characterised by the presence of yellow and pink spots on the cassava leaves (Figure 3 (i). While, a careful observation of the plants revealed a presence of fine spider web between plants leaves with a high concentration of the webs on the plant's apex.

Whereas, few days after the attacks, one could observe a complete change in plant leaves color (from green, tan and brown), with the latter indicating a complete dryness of the leaves which will be followed by the plants (Figure 3 (ii).

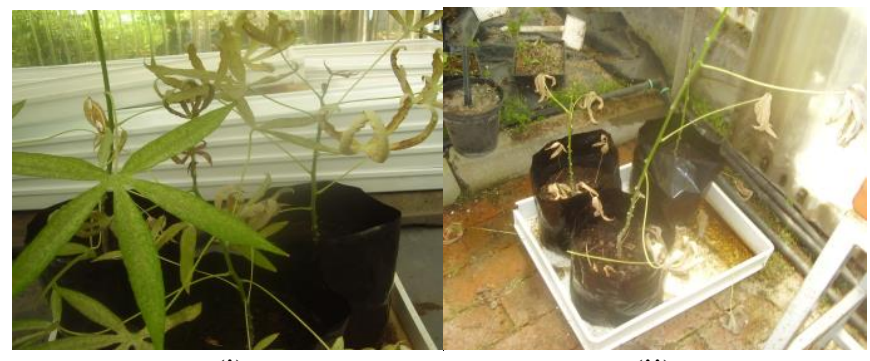

(i)

(ii)

Fig. 3: Red spider mites (Tetranychus urticae) attack on cassava plants (i) and (ii)

\section{Insects/pests Control}

An attempt to stop/control a negative effect of pest's invasion on plants by cutting to infected upper part of plants was unsuccessful, as nearly 4-7 days later a newly formed shoot had the same infestation characteristics (distorted stem and shrinking leaves) Figure 2 (iii). While, the unexpected presence of a natural control; mealybug predator (figure 2 (iv) did not bring any relieve due to the magnitude of mealybug invasion.

Whereas, to mitigate pests attacks, plants were subjected to Oleum treatment. A $5 \mathrm{~mL}$ of Oleum was diluted into $500 \mathrm{~mL}$ of water. The content was mixed by shaking and spread on plants twice a week. However, the treatment which seems to slow the spread of pest attacks during the first two to three months seems unsuccessful during the remaining duration of the study.

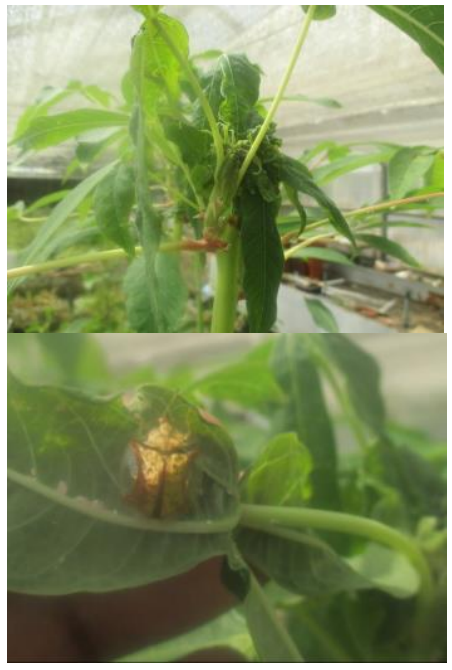

(i) (ii)

Fig. 4: Distorted new cassava shoot (i), Mealybug predator (Cermatulus nasalis) (ii)

\section{CONCLUSION}

In Conclusion, we can say that a cassava cultivation in South Africa at large scale both for community consumption and energy production, will requires a combined effort from all stakeholders i.e. scientists, government, and the community to overcome the above mentioned challenges.

\section{ACKNOWLEDGMENT}

I would like to express my gratitude to the Cape Peninsula University of Technology, through the University Research Fund (URF) cost code: R980 for funding this research.

I would like to express my gratitude to Dr. Richard Mundembe, and all members of the Bioresource Engineering Research Group (BioERG), Department of Biotechnology and Consumer Science, Faculty of Applied Sciences, Cape Peninsula University of Technology, Cape Town Campus.

\section{REFERENCES}

[1] Vincent Okudoh, Cristina Trois, Tilahun Workneh, Stefan Schmidt, 2014, The potential of cassava biomass and applicable technologies for sustainable biogas production in South Africa: A review. Renewable and Sustainable Energy Reviews 39 (2014) 1035-1052 https://doi.org/10.1016/j.rser.2014.07.142

[2] Conte Jr. R.L., 2010. Nutrition per hectare for staple crops

[3] Anselm P. Moshi, Stella G. Temu, Ivo Achu Nges, Gashaw Malmo, Ken M.M. Hosea, 2015, Emrode Elisante, Bo Mattiasson, 2015, Combined production of bioethanol and biogas from peels of wild cassava Manihot glaziovii. Chemical Engineering Journal 279 (2015) 297-306 https://doi.org/10.1016/j.cej.2015.05.006

[4] Sivamani, S., Baskar, R. 2014. Optimization of bioethanol production from cassava peel using statistical experimental design, Environ. Prog. Sus. Energy (n/a-n/a). https://doi.org/10.1002/ep.11984

[5] A.P. Moshi, C.F. Crespo, M. Badshah, K.M. Hosea, A.M. Mshandete, B. Mattiasson, High bioethanol titre from Manihot glaziovii through fed-batch simultaneous saccharification and fermentation in Automatic Gas Potential Test System, Bioresour. Technol. 156 (2014) 348-356. https://doi.org/10.1016/j.biortech.2013.12.082

[6] Barker, A.V. and Pilbeam, D.J. (Eds.), 2015, Handbook of Plant Nutrition (Boca Raton, FL: CRC Press)). 
https://doi.org/10.1201/b18458

[7] Elie Fereche Itoba-Tombo, Seteno Karabo Obed Ntwampe, Jonathan James Andrew Bell, John Baptist Nzukizi Mudumbi \& Tolbert Mhlangabezi Golela, 2017, A decade's (2014-2024) perspective on cassava's (Manihot esculenta Crantz) contribution to the global hydrogen cyanide load in the environment. International Journal of Environmental Studies, 74:1, 28-41. https://doi.org/10.1080/00207233.2016.1227209

[8] Jansson, C., Westerbergh, A., Zhang, J., Hu, X. and Sun, C., 2009, Cassava, a potential biofuel crop in (the) People's Republic of China. Applied Energy, 86(Suppl. 1), S95-S99. https://doi.org/10.1016/j.apenergy.2009.05.011

[9] Chang, S., Zhao, L., Timilsina, G.R. and Zhang, X., 2012, Biofuel development in China: technology options and policies needed to meet the 2020 target. Energy Policy, 51, 64-79. https://doi.org/10.1016/j.enpol.2012.05.084

[10] Ewing, M. and Msangi, S., 2009, Biofuels production in developing countries: assessing tradeoffs in welfare and food security. Environmental Science and Policy, 12, 520-528. https://doi.org/10.1016/j.envsci.2008.10.002

[11] Tilman, D., Socolow, R., Foley, J.A., Hill, J., Larson, E., Lynd, L., Pacala, S., Reilly, J., Searchinger, T., Somerville, C. and Williams, R., 2009. Beneficial Biofuels - the food, energy, and environment trilemma. Science, 325(5938), 270-271. https://doi.org/10.1126/science. 1177970

[12] Bellotti. A.C., Herrera Campo, B.V. and Hyman, G. (2012. Cassava Production and Pest Management: Present and Potential Threats in a Changing Environment. Tropical Plant Biology 5: 39-72. https://doi.org/10.1007/s12042-011-9091-4

[13] Winotai, A., Goergen. G., Tamo, M., Neuenschwander, P., 2010. Cassava mealybug has reached Asia. Biocontrol News Inf 31: 10N-11N.

[14] Parsa, S., Kondo, T., Winotai, A., 2012. The Cassava Mealybug (Phenacoccus manihoti) in Asia: First Records, Potential Distribution, and an Identification Key. Plos One, 7 (10) e47675 https://doi.org/10.1371/journal.pone.0047675

[15] 53. Pyšek. P. and Richardson, D.M., 2010. Invasive species, environmental change and management, and health. Annu. Rev. Environ. Resour. 35: 25-55. https://doi.org/10.1146/annurev-environ-033009-095548

[16] Goldblatt, A, Bormann, T. V., Kotze, I., Corcoran, B., Botha, M., Brinkcate T., Hawkins, H., Rose, M., Morris, D. 2010. AGRICULTURE: FACTS \& TRENDS, South Africa. WWF (The Green Trust), 1-27

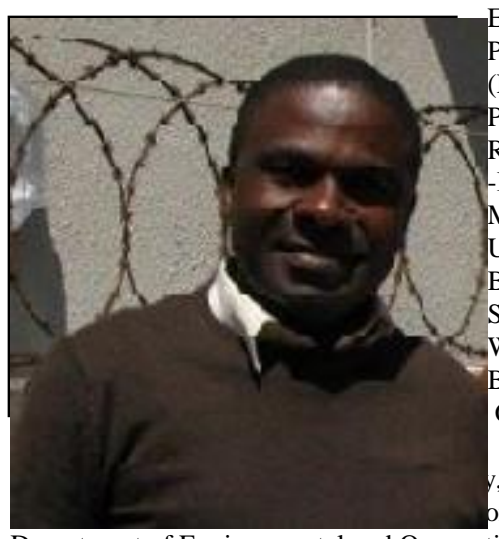
Elie F. Itoba-Tombo PhD-Environmental Studies (Environmental Health)- Cape Peninsula University of TechnologyRSA

Master's (MTech) Environmental Management-2010.Cape Peninsula University of Technology RSA BSc Honours- Earth Environmental Sciences- 2004- University of the Western Cape-, RSA

Bachelor (BSc) Option: Physical Geography- 1996 - University of

Environmental Geology, nmrntal Economics V) in the Department of Environmental and Occupational Studies-

Environmental Management Programme; from 2007 to Present

Publications:

Books chapters:

Elie Ferche Itoba-Tombo, Abraham Thomas, Stam M. Ed. 2018. Spatial and temporal distribution of pollutants from different land-use/land-cover types of the Bottelary River catchment. In New Horizons in Wastewaters Management: Emerging Monitoring and Remediation Strategies. Prof. Dr. Elvis Fosso-Kankeu (Ed.). Nova Science Publishers,Inc. (NOVA), ISBN: 978-1-53615-659-1

E. F. Itoba Tombo, S.K.O. Ntwampe and J. B. N. Mudumbi, 2017. Leaching of cyanogens and mycotoxins from cultivated Cassava into agricultural soil: Effects on groundwater quality. in Aflatoxin -Control, Analysis, Detection and Health Risks, Dr. Lukman Bola Abdulra'uf (Ed.), InTech, ISBN: 978-953-51-5464-

Justine O. Angadam, Nkosikho Dlangamandla, Seteno K. O. Ntwampe,* Elie F. Itoba Tombo, and Boredi S. Chidi. 2019. Sustainable Nepenthes mirabilis Facilitated Recovery of Reducing Sugars from Grape Pomace. BioResources, 14(2): 3944-3960, DOI: 10.15376/biores. 14.2.3944-3960

John Baptist Nzukizi Mudumbi, Adegbenro Peter Daso, Okechukwu Jonathan Okonkwo, Seteno Karabo Obed Ntwampe, Tandi E. Matsha, Lukhanyo Mekuto ,Elie Fereche Itoba-Tombo, Adewole T. Adetunji and Linda L. Sibali. 2019. Propensity of Tagetes erecta L., a Medicinal Plant Commonly Used in Diabetes Management, to Accumulate Perfluoroalkyl Substances. Toxics 2019, 7 (18); doi:10.3390/toxics7010018

E. F. Itoba-Tombo, Seteno Karabo Obed Ntwampe, John Baptist Nzukizi Mudumbi, Lukhanyo, Mekuto, Enoch Akinbiyi, Akinpelu and Ogheneochuko U. Oputu,

2018. Rapid Identification of Cunninghamella bertholletiae's Toxins/Secondary Metabolites

via a Fermentation Technique. 10th International Conference on Advances in

Science, Engineering, Technology and Healthcare (ASETH-18); Nov. 19-20, 2018 at

Cape Town, South Africa doi.org/10.17758/EARES4.EAP1118110.

N. Dlangamandla, S.K.O. Ntwampe, J.O. Angadam, E.F. Itoba-Tombo and B.S. Chidi,

2018. Production of Low (C 1 to C 3 ) and High Carbon Content (C $4+$ ) Alcohols Under

Aerobic Conditions Using Total Reducing Sugar from Mixed Agro-Waste. 10th International Conference on Advances in

Science, Engineering, Technology and Healthcare (ASETH-18); Nov. 19-20, 2018 at

Cape Town, South Africa. doi.org/10.17758/EARES4.EAP1118256.

Lionnel A. N. NDEBA NGANONGO, Seteno K.O. Ntwampe, S. Szabolcs and

E.F. Itoba-Tombo, 2018. The Application of ADM/ASM Interface in Sumo Wide Plant

Model. 10th International Conference on Advances in Science, Engineering, Technology and Healthcare (ASETH-18); Nov. 19-20, 2018 at Cape Town, South Africa DOI: https://doi.org/10.17758/EARES4.EAP1118257.

L. Mekuto, Y.M. Kim, S.K.O. Ntwampe, M. Mewa-Ngongang, J.N. Mudumbi, N

Dlangamandla, E.F. Itoba-Tombo, E.A. Akinpelu, 2018. Heterotrophic nitrification-aerobic

denitrification potential of cyanide and thiocyanate degrading microbial communities under

cyanogenic conditions. Environmental Engineering Research. doi.org/10.4491/eer.2018.147

John Mudumbi, Seteno Karabo Obed Ntwampe, Lukhanyo Mekuto, Tandi E. Matsha,

Elie Fereche Itoba-Tombo. 2018. The role of pollutants in Type 2 Diabetes Mellitus

(T2DM) and their prospective impact on phytomedicinal treatment strategies.

Environmental Monitoring and Assessment. https://doi.org/10.1007/s10661-018-6634-2

Mekuto L., Kim Y. M., Ntwampe S. K. O., Mewa-Ngongang M.,Mudumbi J.B. N.,

Dlangamandla N., Itoba-Tombo E. F. 2018. Heterotrophic Nitrification-Aerobic

Denitrification Potential of Cyanide and Thiocyanate Degrading Microbial

Communities under Cyanogenic Conditions. Section: SEWAGE MANAGEMENT

AND TREATMENT. 10th Eastern European Young Water Professionals Conference

IWA YWP, 7-12 May 2018, Zagreb, Croatia. Pp. 243 - 244. ISBN: 
$978-953-8168-23-9$

John Baptist Nzukizi Mudumbi, Seteno Karabo Obed Ntwampe, Lukhanyo Mekuto,

Elie Fereche Itoba-Tombo, Tandi E. Matsha, 2017, Are aquaporins (AQPs) the

Gateway that conduits nutrients, persistent organic pollutants and perfluoroalkyl

substances (PFASs) into plants? Springer Science Reviews, 5(1-2), pp. 31-48, DOI: $10.1007 / \mathrm{s} 40362-017-0045-6$

John Baptist Nzukizi Mudumbi, Seteno Karabo Obed Ntwampe, Tandi Matsha,

Lukhanyo Mekuto, Elie Fereche Itoba-Tombo. 2017. Recent developments in

Polyfluoroalkyl compounds research: A focus on human/environmental health

impact, suggested substitutes and removal strategies. Environmental

Monitoring and Assessment, 189(8), p.402.

Itoba-Tombo, E.F., Obed Ntwampe, S.K., Bell, J.J.A., Nzukizi Mudumbi, J.B. and

Mhlangabezi Golela, T., 2017. A decade's (2014-2024) perspective on cassava's

(Manihot esculenta crantz) contribution to the global hydrogen cyanide load in the

environment. International Journal of Environmental Studies, 74(1), pp.28-41.

E. F. Itoba-Tombo, S. K. O. Ntwampe, A. Waxa, A. Paulse, and E. A. Akinpelu.

2016. Screening of fungal (Cunnighamella bertholletiae) pathogenic activity on

Microbial community in cassava (Manihot esculenta crantz) cultivated soil. Int'l Conf. on Advances in

Science, Engineering, Technology \& Natural Resources
(ICASETNR-16) Nov. 24-25,

2016 Parys (South Africa). ISBN 978-93-84468-79-8

Enoch Akinbiyi Akinpelu, Seteno Karabo Obed Ntwampe, Lukhanyo Mekuto and Elie

Fereche Itoba Tombo. 2016. Optimizing the Bioremediation of Free Cyanide

containing Wastewater by Fusarium oxysporum grown on Beetroot Waste using

Response Surface 2016 Vol II WCECS 2016, October 19-21, 2016, San Francisco,

USA.ISBN: 978-988-14048-2-4 ISSN: 2078-0958 (Print); ISSN: 2078-0966 (Online), 664 - 670 